\title{
ENGEL ENIKÖ
}

121542@student.ujs.sk

PhD.-hallgató (Selye János Egyetem Tanárképző Kar, Történelem Tanszék

Történelemdidaktika Tanulmányi Program)

VAJDA BARNABÁS

vajdab@ujs.sk

egyetemi docens (Selye János Egyetem Tanárképző Kar, Történelem Tanszék)

\section{A képi források és az illusztrációk didaktikai szempontjairól - szlovákiai alapiskolás történelemtankönyvek vizsgálata alapján}

\author{
On the didactical aspects of images as sources and illustrations \\ - based on research of some Slovakian elementary history \\ schoolbooks
}

\begin{abstract}
Images are important parts of school textbooks. They do not only have an illustrative function, but they are also able to motivate students, and even new knowledge can be gained through them since they can help to systematize knowledge. Although the number of illustrations has increased in history textbooks over the years, and even if images have shown a great variety, it does not mean that they are better in pedagogical quality.

In our study, we examine pictures from current history textbooks that have been used in primary schools in the Slovak Republic. First we analyse the structure of the textbooks, then the didactical functions of the pictures/figures, with special reference to the properties of the maps in the textbooks. We also make suggestions how the pictorial material of these books could be changed to make them more resource-centric, didactically up-to-date, and more effective. In our analysis we conclude that the authors did not equip these textbook pictures with appropriate
\end{abstract}


didactic apparatus. Although our textbooks are lined up with plenty of colourful and varied illustrations, due to the size of the images and the quantity and quality of the questions and tasks associated with them, these are merely illustrations and not resources. It is a bitter experience that in Slovakia the preparation of taxonomized tasks, missing from textbooks, is left to teachers.

\section{KEYWORDS}

images, sorces, illustrations, textbooks, Slovakia

DOI 10.14232/belv.2021.2.6

https://doi.org/10.14232/belv.2021.2.6

Cikkre való hivatkozás / How to cite this article:

Engel Enikő - Vajda Barnabás (2021): A képi források és az illusztrációk didaktikai szempontjairól - szlovákiai alapiskolás történelemtankönyvek vizsgálata alapján. Belvedere Meridionale vol. 33. no. 2. 133-151. pp

ISSN 1419-0222 (print)

ISSN 2064-5929 (online, pdf)

(Creative Commons) Nevezd meg! - Így add tovább! 4.0 (CC BY-SA 4.0)

(Creative Commons) Attribution-ShareAlike 4.0 International (CC BY-SA 4.0)

www.belvedere-meridionale.hu

\section{BEVEZETÉS}

A vizuális igények kielégítése fontos szempont a tanórán, hiszen a huszonegyedik század diáksága elvárja ezt. A tankönyvek nem maradhatnak alul a vizualitásban - habár a mindenkori legfejlettebb online vizuális kultúrához képest a tankönyvek, még a digitálisak is, valószínűleg mindig lépéshátrányban lesznek. Feltehetjük a kérdést, a tankönyvekben szükség van képekre - beleértve a „kép” fogalomba az összes lehetséges tankönyves vizuális impulzustípust. (A tankönyvi illusztrációk osztályozásáról lásd MARóDI 2013; V. Molnár László osztályozását lásd V. Molnár 2001.) Kezdve a legegyszerübb képi szemléltetőanyag jelenlétével, folytatva a tankönyvi képek motivációs szerepével és a képek által is lehetséges új ismeretek elsajátításával egészen addig, hogy milyen szerepük lehet a vizuális impulzusoknak a tanult ismeretek rendszerezésében, összefoglalásában és a hozzájuk kapcsolódó tananyag értelmezésében. megállapíthatjuk, a tankönyves képekre szükség van.

Amint azt már korábban is vizsgáltuk és kimutattuk (VAJDA - BÉNYI 2011), a történelem-tankönyves képek száma és minősége az utóbbi évek tankönyveiben általában látványosan emelkedett és javult. Ugyanakkor ma is helyénvalónak tartjuk a kérdést, hogy a vizuális dizájn modernsége automatikusan jelent-e tanítási korszerüséget és/vagy hozzáadott pedagógia értéket. 
A magyar történelemdidaktikai szakirodalomban viszonylag kis figyelem irányul a történelem-tankönyvi képek didaktikai szerepének elemzésére. Bár e téren több meghatározó publikációt ismerünk (FISCHERNÉ - KOJANITZ 2007; FISCHERNÉ 2008; GÉCZI 2008), azonban ezek többsége elsősorban és szinte kizárólag a tankönyves képi elemek illusztratív és fogalomalkotó szerepére, funkcióira irányul, mint pl. Maródi Ágnes tanulmánya. (MARóDi 2013) Sovány vigasz, hogy az e témába vágó szlovák nyelvü szakirodalom még ennél is szükebb.

Egy pillanatra sem vitatjuk, hogy a megfelelő képek, ábrák stb. révén a tanulók a verbális és nonverbális csatornákon is képesek az ismeretszerzésre, és a képek segíthetik a helyes képzetek kialakítását és az elvont ismeretek megértését. (KOJANITZ 2004) Ugyanakkor úgy tapasztaljuk, hogy a tankönyvekben rengeteg gyönyörü kép nagyon sokszor nem szolgál oktatási célokat, így ezek akár haszontalannak is mondhatók. Ahogy a tankönyves képek iránt (szerintünk nagyon jogos) kritikát megfogalmazó Závodszky Géza fogalmaz: „Azt gyanítjuk, hogy olykor csak azért kerül be egy-egy kép a tankönyvbe, hogy az adott oldal ne maradjon ábra nélkül."

Úgy véljük, hogy csak a forrásként használható, tehát a megfelelő kérdésekkel és feladatokkal ellátott képek képesek támogatni az aktív tanulói részvételt, annak az alapvetésnek a szellemében, hogy a korszerü tanulás nem a tudomány által kidolgozott és a tanár által közölt ismeretek bemagolását jelenti. (KAPOSI 2020. 13) Felfogásunk szerint a történelemtankönyvekben szükséges volna meghaladni az illusztrációs szemléletet, helyette a képeknek mint tudásszerzési forrásoknak a tanulók általi alkalmazását kell célul tüzni - természetesen mértékkel. Más szavakkal és kissé sarkosan fogalmazva: Mi csak a didaktikailag átgondolt és céltudatosan didaktikai apparátussal ellátott képet tekintjük pedagógiai célú képnek; szerintünk minden más (csak) illusztráció. (VAJDA 2018. 115-116.)

\section{A VIZSGÁLT TANKÖNYVEK}

Az általunk ebből a szempontból megvizsgált szlovákiai alapiskolák (a magyarországi fogalmak szerint: általános iskolák) 5., 6. és 7. évfolyamában jelenleg használatos történelemtankönyvek egy tankönyvsorozat részét képezik:

- Miháliková, Margita - Tonková, MÁria (2012): Történelem az alapiskola 5. osztálya számára. Prešov, Slovenské pedagogické nakladatel'stvo.

- Krasnovský, Branislav - Miháliková, Margita - Tonková, Mária (2016): Történelem az alapiskola 6. osztálya számára és a nyolcosztályos gimnázium 1. osztálya számára. Bratislava, Slovenské pedagogické nakladatel'stvo.

- LukaČKa, JÁN - Tonková, MÁria- KaČíreK Ĺuboš - SoŇa Hanová (2012): Történelem az alapiskola 7. osztálya számára és a nyolcosztályos gimnázium 2. osztálya számára. Prešov, Slovenské pedagogické nakladatel'stvo.

Az alábbiakban első lépésként a tankönyvek struktúráját vizsgáljuk. Utána különböző szempontok szerint csoportosítjuk a tankönyvek képeit, valamint elemzés alá vetjük a képeknek a tanítási folyamatban betöltött funkcióit, a didaktikai feldolgozottságukat, külön kitérve a tankönyvekben szereplő térképek tulajdonságaira. Ezenkívül megvizsgáljuk, hogy a tankönyvek 
képi elemei milyen kapcsolatban állnak a tankönyvi leíró szöveggel, köztük az elöszóban leírtakkal. Végül javaslatokat is megfogalmazunk azzal kapcsolatban, hogy mit lehetne megváltoztatni ezeknek a könyveknek a képi anyagában avégett, hogy azok forrásközpontúbbá és didaktikai szempontból korszerübbé, hatékonyabbá váljanak. Megjegyezzük, hogy elemzésünk során a képek közé sorolunk mindenfajta képi impulzust: fotókat, festményeket, rajzokat, tárgyak fotóit, térképeket stb. Jelen elemzésünk során viszont nem soroljuk a képek közé, és így nem is elemezzük, a könyvekben megjelenő, díszként funkcionáló apró rajzokat.

\section{A TANKÖNYVEK STRUKTÚRÁJA}

A tankönyvekre vetett első pillantás alapján a könyvekben található képek strukturálisan és stílusbelileg is hasonlóak, közös általános jellemzőjük, hogy nagyon színesek, látványosak, rengeteg képet tartalmaznak.

A három említett tankönyv terjedelme közel megegyezö. Az 5. évfolyamban használt tankönyv 80 oldalt tesz ki (borító nélkül), a 6. évfolyamos 96 oldalt, a 7. évfolyamos pedig 104 oldalt (szintén borító nélkül számolva). Mindhárom könyvben a képek száma meghaladja a 200at. Az 5. évfolyamos tankönyv 207 darab képet tartalmaz; a 6. évfolyamos 270 képet; a 7. évfolyamnak szánt tankönyvben pedig 235 kép található. Ha leszámítjuk a könyv járulékos részeit (mint előszó, földrajzi nevek jegyzéke, irodalomjegyzék, név- és tárgymutató, tartalomjegyzék), akkor kiderül, hogy átlagosan minden egyes oldalon 4 kép található, ami alátámasztja azt az állítást, hogy egy illusztrációban gazdag, vizuálisan látványos tankönyvsorozatról van szó.

Múfaji besorolás szempontjából a képek között felfedezhetünk fotókat, festményeket, tárgyak képeit, rajzolt ábrákat, térképeket és néhány diagramot. Ha a müfaji besoroláson túl történelemdidaktikai szempontú osztályozást alkalmazunk, akkor a következő négy föbb kategória rajzolódik ki:

a. képek, amelyekhez nem csatlakozik semmilyen didaktikai apparátus;

b. magyarázattal (azaz leíró szöveggel) ellátott képek;

c. a magyarázat mellett kérdéssel és/vagy feladattal ellátott képek;

d. olyan képek, amelyekhez leíró szöveg nem tartozik, viszont van hozzájuk kérdés és/ vagy feladat.

A legelszomorítóbb kategória kétségkívül az, mikor a tankönyvben található képhez semmilyen információ nem társul: se kérdés, se feladat, de még magyarázat sem. Ilyenkor a tanuló kénytelen a leíró szövegből kihámozni (ha egyáltalán veszik a fáradságot), hogy mit ábrázolhat az adott kép, a pedagógus pedig esetleg azon is eltöpreng, hogy milyen pedagógiai célt szolgál az adott illusztráció.

A második (b) kategória kissé pozitívabb, hiszen ezekben az esetekben legalább valamilyen leírást kap a tankönyvfelhasználó a képhez csatolva. Ez legtöbbször magyarázat a képröl, pontosabban a képpel kapcsolatos eseményről, személyröl, jelenségről. Talán nem túlzás azt állítani, hogy ezek az ,ürügy képek”: a képek ürügyek ahhoz, hogy a tankönyvszerzők tovább beszélhessenek... 
Didaktikai szempontból a harmadik (c) és a negyedik (d) kategóriák ígéretesebbek. Bár kétségtelen, hogy a képek iránti érdeklődés eleve és önmagában tanulásmotiváló hatású lehet (KoJANITZ 2004), azonban ha és amennyiben a képekhez valamilyen feladat kapcsolódik, akkor a képek esélyt kapnak, hogy valamilyen ismeret vagy valamilyen képességfejlesztés forrássá váljanak.

A képekhez kapcsolt kérdéseknek sokféle pozitív hatásuk lehet:

- felhívhatják a tanulók figyelmét valamilyen fontos (történelmi szempontból releváns) részletre, ld. Ptolemaiosz-térkép (7. évfolyamos tankönyv 58. oldal; lásd 1. ábra)

- gyakoroltathatják az önálló információgyüjtést, ld. Érsekújvár (7. évfolyamos tankönyv 82. oldal; lásd 2. ábra)

- gyakoroltathatják a vizuális eredetű információk hatékony feldolgozását, ld. sumér társadalmi esemény (6. évfolyamos tankönyv 21. oldal; lásd 3. ábra)

- a térképek és statisztikai alapú grafikonok esetében gyakoroltathatják az adatelemzést és -feldolgozást, ld. Bányászat a középkorban a mai Szlovákia területén (7. évfolyamos tankönyv 40. oldal; lásd 4. ábra)

\section{1. ábra: Ptolemaosz-térkép}

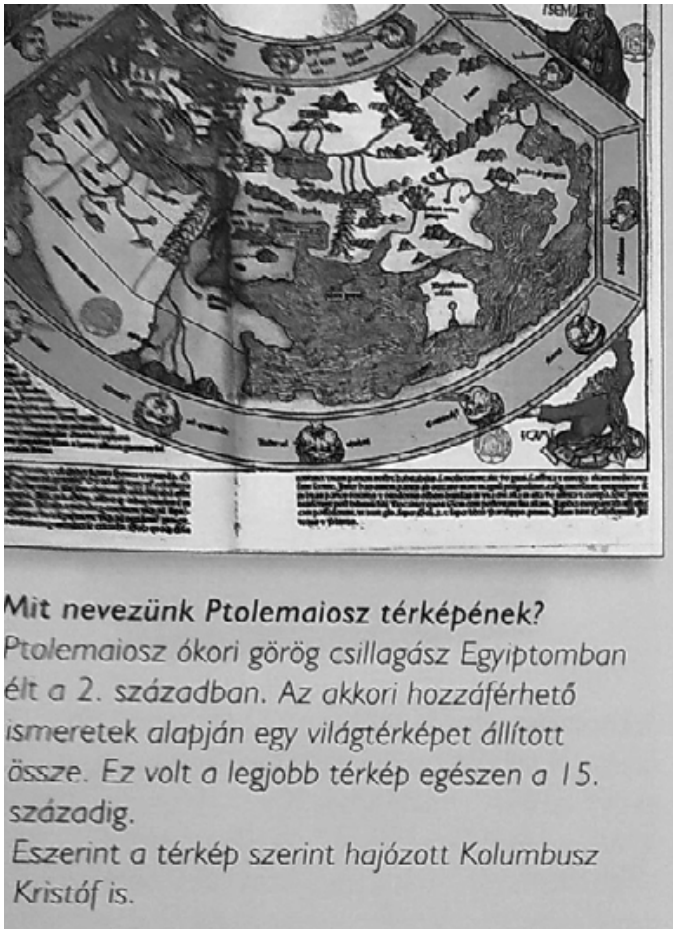

Forrás: LuKAČKA, JÁN - TONKOvÁ, MÁRIA- KAČÍREK ĹUBOŠ- SoŇA HANOvÁ (2012): Történelem az alapiskola 7. osztálya számára és a nyolcosztályos gimnázium 2. osztálya számára. Prešov, Slovenské pedagogické nakladatel'stvo. 58. 


\section{2. ábra: Érsekújvár}

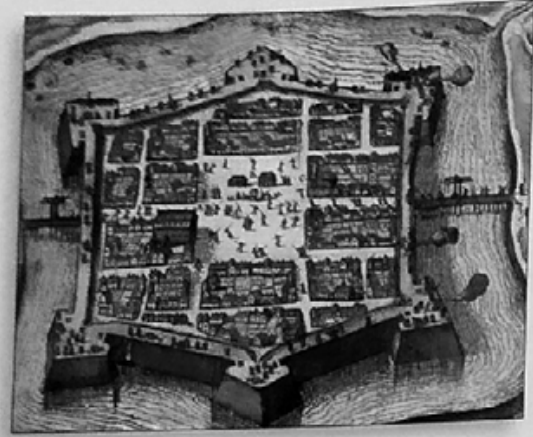

Érsekújvár (Nové Zámky)

Az érsekújvári eród "zöld mezón" keletkezett, és az ország sik vidékeit védte. Az akkori legkorszerúbb haditechnika akapjón építették. Az épitmény csillag alakú, ami lehetóvé tette, hogy a legtökéletesebb módon tudjanak védekezni a tómadások ellen.

Keressétek meg az interneten Szlovákia múhold segitségével készült térképét, és állapitsótok meg, hogy hazánk területén még hol maradt fenn hasonló típusú eródítmény! A hollandiai Naarden városról és az észak-olaszországi Palmanova város eróditményéról készült múholdas felvételeken jellegzetes csillag alakú eróditményeket tekinthettek meg.

Forrás: LuKaČKa, JÁN - TONKová, MÁRIA- KaČírek Ĺuboš- SoŇA Hanová (2012): Történelem az alapiskola 7. osztálya számára és a nyolcosztályos gimnázium 2. osztálya számára. Prešov, Slovenské pedagogické nakladatel'stvo. 82.

\section{3. ábra: Sumér társadalmi esemény}

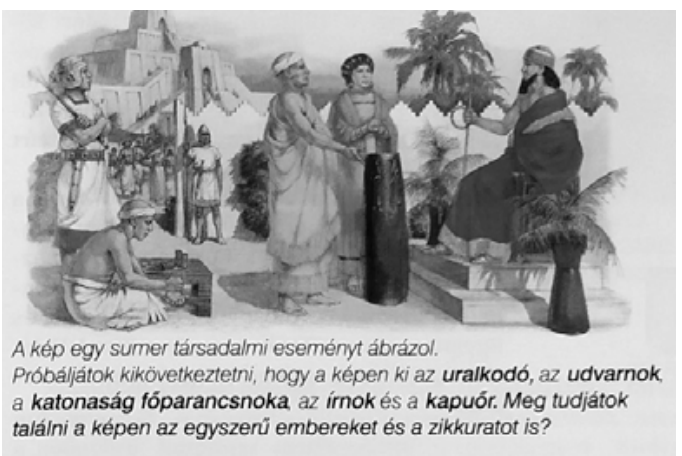

Forrás: Krasnovský, Branislav - Miháliková, Margita - Tonková, Mária (2016): Történelem az alapiskola 6. osztálya számára és a nyolcosztályos gimnázium 1. osztálya számára. Bratislava, Slovenské pedagogické nakladatel'stvo. 21. 


\section{4. ábra: Bányászat a középkorban a mai Szlovákia területén}

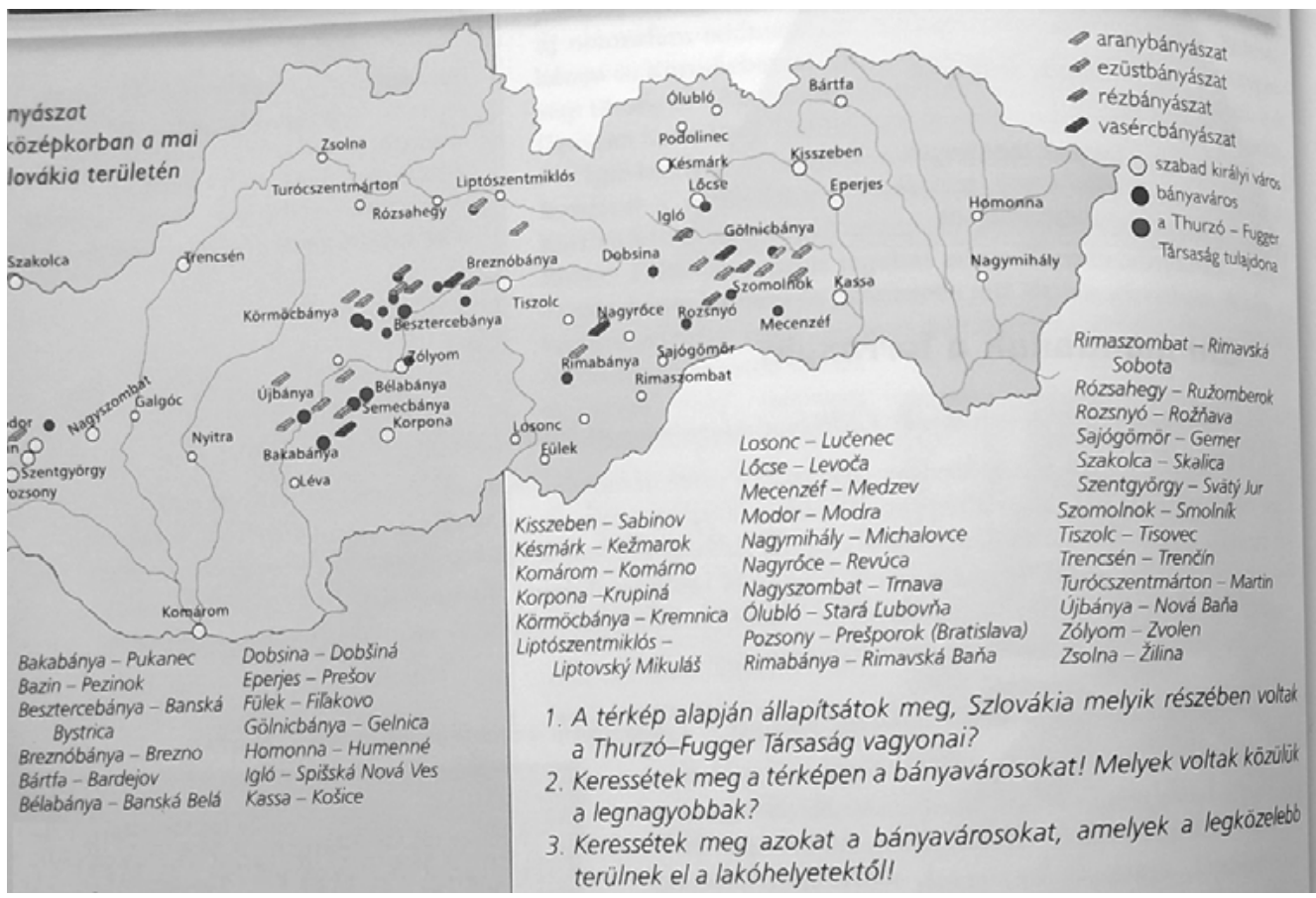

Forrás: LuKaČKa, JÁN - TONKová, MÁRIA- KaČíreK ĹuBoš- SoŇA Hanová (2012): Történelem az alapiskola 7. osztálya számára és a nyolcosztályos gimnázium 2. osztálya számára. Prešov, Slovenské pedagogické nakladatel'stvo. 40.

Kojanitz László kutatása szerint a tankönyvekben a képi elemek minimum 25-30\%-ához kellene, hogy valamilyen kérdés vagy feladat tartozzon annak érdekében, hogy a képek ne csak mint díszítő illusztrációk müködjenek, hanem mint hasznos források, amelyek a tankönyvet didaktikai szempontból modernebbé és hasznossá tehetik. (KoJANITZ 2004)

Az általunk vizsgált tankönyvekben a megfigyelt kategóriák előfordulási arányait az alábbi diagram szemlélteti: 
1.diagram: Az 5., 6. és 7 évfolyam tankönyvi ábratípusainak aránya

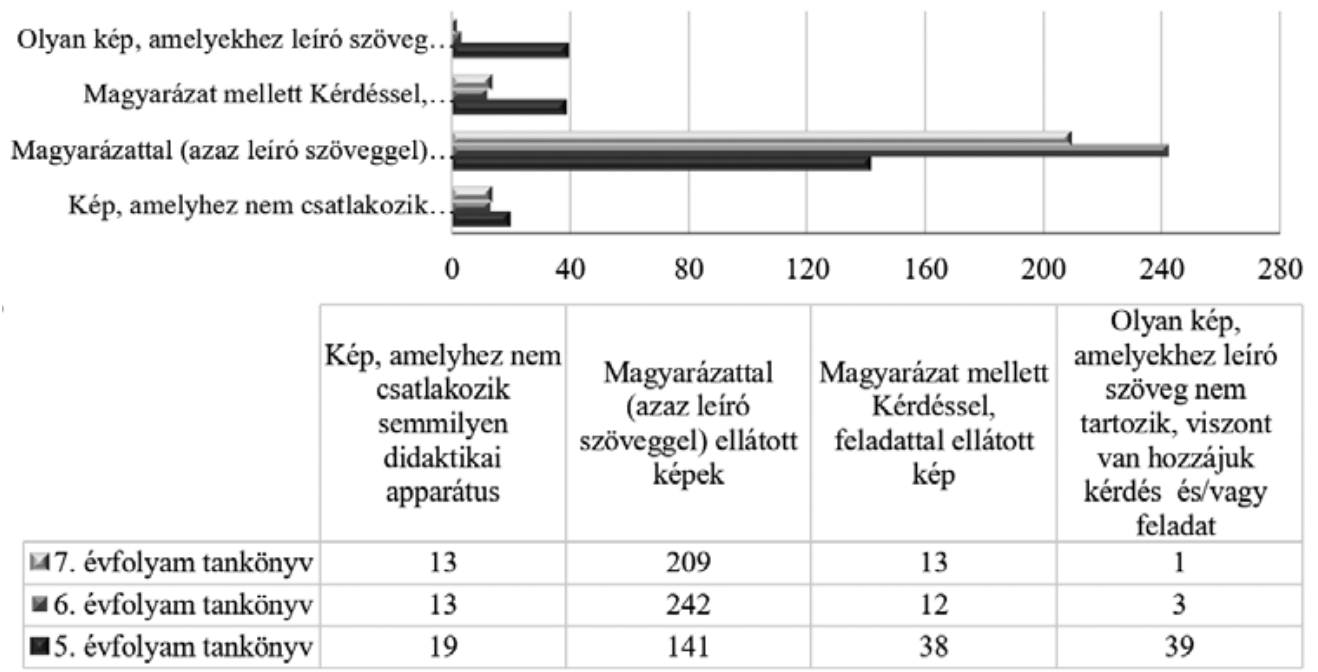

Ha ragaszkodunk ahhoz a nézethez, hogy a tankönyvekben található képek csak akkor minősülnek forrásnak, ha azokhoz didaktikai apparátus társul (VAJDA 2018. 115), akkor nagyon rossz arány figyelhetö meg a fenti könyveknél, ahogy az a diagramban látható.

A 7. évfolyam tankönyvében a képek 14\%-hoz kapcsolódnak kérdések vagy feladatok. A 6 . évfolyam esetében ez mindössze 5,6\%-hoz. Egyedül az 5. évfolyamos tankönyv képei haladják meg a $32 \%$-ot.

Kifejezetten feltünő még a „,csak” szöveges magyarázattal ellátott képek mennyisége. Mindhárom könyvnél arányaiban jóval több az ilyen típusú kép. Taxonómiai szempontból nincs sok hasznuk ezeknek a képeknek, hiszen a hozzájuk csatolt információk mindössze az ismeretek szintjén közelítenek a tanuló felé, adatokat, információkat sorakoztatva fel. Még ha a tanulók megnézik is ezeket a képeket, és elolvassák is a hozzájuk tartozó szöveget, akkor sem valószínü, hogy ettől bármely képességük fejlődnék, kivéve talán az olvasási készséget. A szöveges forrásokkal ellentétben, amelyeket az elemzéskor muszáj elolvasni, az illusztratív képek hajlamosak rá, hogy megmaradjanak a primer vizuális impulzusok szintjén. (VAJDA 2020. 37.)

Technikai-szerkesztési értelemben helyes, hogy az elemzett könyvekben a belíveken található tankönyvi illusztrációk jellemzően azokon a helyeken társulnak a leíró szöveghez, illetve a szövegközben ott nyernek elhelyezést, ahol az illusztráción ábrázolt személyről, tárgyról, eseményről, összefüggésről szó esik. Történelemdidaktikai igényű megközelítésben ugyanakkor a tankönyvi leíró szöveg és a képek közös kapcsolódási pontjairól, és föleg az e kapcsolatban rejlő pedagógia haszon feltárásáról azt mondhatjuk, hogy a különböző tankönyvi fejezetek témája és a melléjük szerkesztett képek-illusztrációk didaktikai koherenciája egy sokkal nagyobb kihívás - ahogy azt az alábbiakban kifejtjük. 


\section{A KÉPEK VIZSGálata}

A képek mennyiségével kapcsolatban már megállapítottuk, hogy az elemzett tankönyvsorozat mindhárom része rengeteg képet tartalmaz. Csakhogy a jelek szerint ezt a mennyiségi többletet nem kíséri minőségi többlet, amennyiben a rengeteg kép nagyon nagy része (emlékeztetünk: a tankönyvsorozat három kötetében összesen 712 darab kép található) sem technikai szempontból, sem didaktikai szempontból nem alkalmas pedagógiai célokra. Nagy gond a képek (technikai értelemben vett) nem megfelelő méretü megjelenítése. Mind a történelmi forrásokról (pl. okiratokról) készült képek, mind az egyéb képek (személyek, helyek stb.) rendkívül aprók. Például az ötödik évfolyam tankönyvének a 26. oldalán található Zobori adománylevél (5. ábra) a tankönyvben alig $7,5 \mathrm{~cm} \times 4,5 \mathrm{~cm}$, ami lehetetlenné teszi nemhogy a szöveg olvashatóságát, de puszta megfigyelését is.

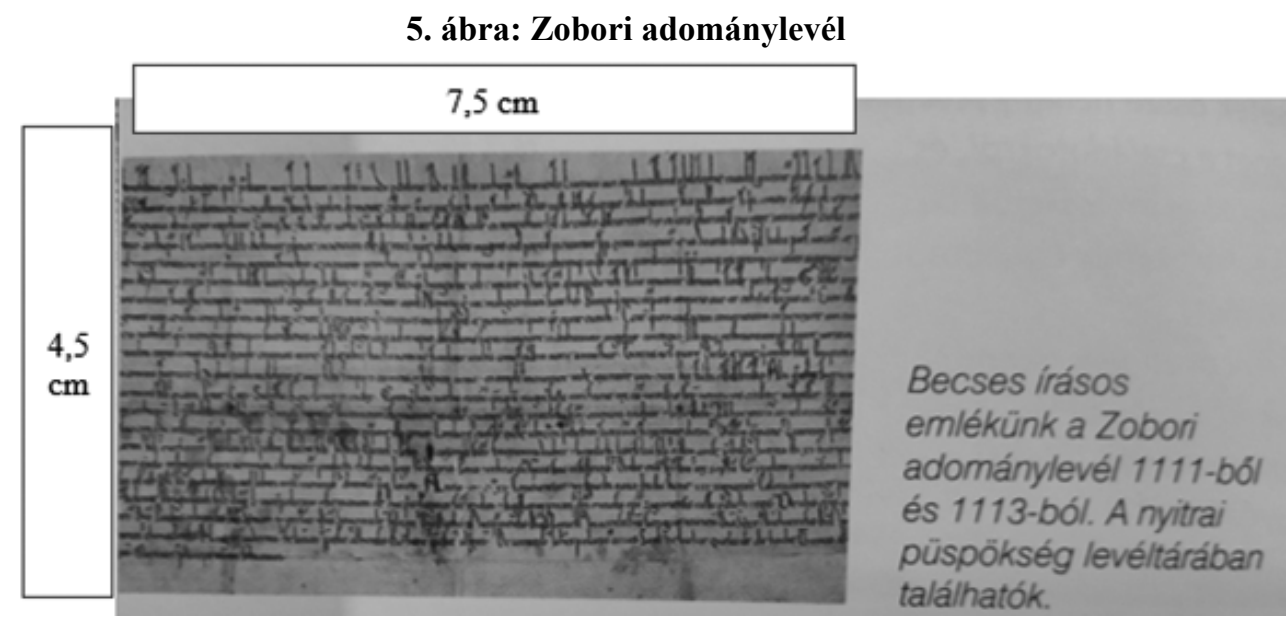

Forrás: MihÁLIKovÁ, MARGITA - Tonková, MÁRIA (2012): Történelem az alapiskola 5. osztálya számára. Prešov, Slovenské pedagogické nakladatel'stvo. 26.

Ezzel nem azt mondjuk, hogy a Zobori adománylevél, ha nagyobb méretben lenne, akkor abban a formában használható lenne forrásnak. Hiszen az adománylevél nyelvezete, mérete és írásképe a diákok számára nem teszi lehetővé az elemzését; viszont megfelelő nyelvezetre és külalakra átalakítva írásos forrássá válhatna. Valójában sokkal célszerübb volna így, tehát fordításban és didaktikailag elökészítve beemelni a tankönyvbe, nemcsak ezt, hanem bármely egykori iratot, mint így: egy apró illusztrációként, amiből csak az vehető ki, hogy egy 'régi teleírt papír' . Úgy véljük, eredményesebb lenne kevesebb, de nagyobb méretü, és részleteiben jobban elemezhető képeket beemelni a tankönyvekbe, amik a munkáltató munkamódszer alapjává és/ vagy támogatóivá tudnának válni. (F. DÁRDAI 2001)

Természetesen nem mindegy, hogy milyen taxonómiai minőségű kérdés, feladat vagy gyakorlat kapcsolódik a képekhez. Mint az előző diagramban láthattuk, a megvizsgált tankönyvsorozatban a kérdéssel és feladattal ellátott képek száma viszonylag alacsony. Ha továbbmenve taxonómiai és operacioanalizációs szempontból is megvizsgáljuk a kérdéseket, akkor az a 
probléma merül fel, hogy nagy részük esetében a kérdések egyáltalán nem konkrétan a képekre irányulnak, hanem igazából az előzetes tudást kívánják feltérképezni. Ezek a kérdések a: Hallottatok-e már ...? és Tudtátok-e, hogy...? típusú

kérdések; valójában szimpla eldöntendő kérdések, amelyekre igennel vagy nemmel lehet válaszolni. Például az 5 . évfolyamos tankönyv 22. oldalán találunk egy képet egy világháborús emlékmüröl. (6. ábra)

\section{6. ábra: Háborús áldozatok emlékmúve}

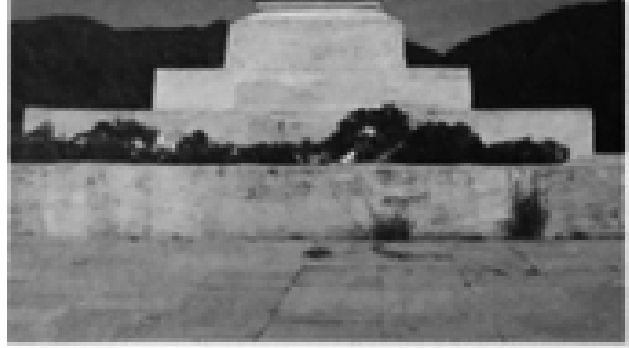

Találkoztatok már ilyen emlékmưvel? A háborúban sok katona gyakran nyomtalanul eltünik. Ezért az emberek ilyen emlékmüveket is állitanak, hogy igy, jelképesen fejezzék ki tiszteletüket az összes elesett katonának.

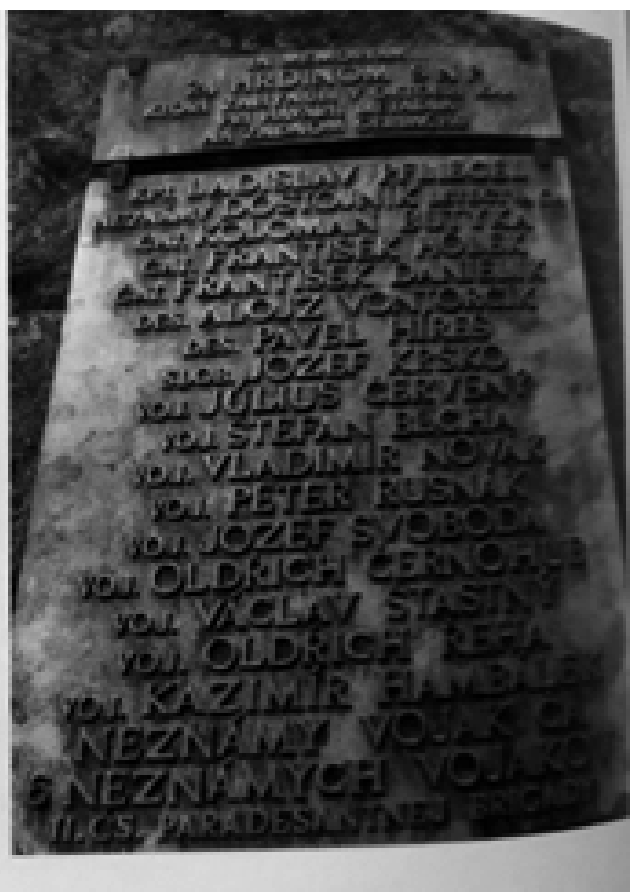

Forrás: MihÁliková, MARgITA - TONKOvÁ, MÁRIA (2012): Történelem az alapiskola 5. osztálya számára. Prešov, Slovenské pedagogické nakladatel'stvo. 22.

A képhez egy rövid magyarázat társul és egy kérdés, hogy Találkoztatok-e már ilyen emlékmüvel? A kérdés didaktikai szempontból mindössze a figyelemfelkeltést szolgálja. Abban az esetben látnánk értelmét az ilyen típusú kérdéseknek, ha a diákok valószínüsíthető igen válasza után további kérdés következne, például: Ha igennel válaszoltatok, akkor mit tudtok róla?

Kissé továbbgondolva a feladatot, további kérdéseket és feladatokat lehetne a mellékelt képhez csatolni:

Olvasd le az emlékmüröl, hogy milyen történelmi eseményben résztvevők tiszteletére állitották! 
Vedd számba (készits listát, fényképezd le stb.), hogy a Te településeden kiknek állitottak hasonló emlékmüvet!

Fogalmazz meg legalább két feltételezést, hogy miért férfiak neve szerepel (többségében) az emlékmüvön!

Sajnos ilyen típusú képi források, amelyekhez több kérdés és feladat is társul, szinte egyáltalán nem fordulnak elő egyik általunk vizsgált szlovákiai kiadványban sem. Mindössze néhány esetben tapasztaljuk, hogy a tankönyvben közölt forrásokhoz kettőnél több kérdés vagy feladat kapcsolódik. Pl. a hetedikes tankönyv 64 oldalán olvashatunk két szemelvényt a földrajzi felfedezésekkel kapcsolatban. Ehhez az írott forráspároshoz egy feladat és két kérdés is kapcsolódik. Az általunk vizsgált tankönyvek képei esetében legtöbbször legfeljebb egy-egy eldöntendö kérdés szerepel, esetleg hozzácsatolt rövid történet, esélyt sem adva a tanuló önálló gondolatainak kifejtésére. Ezek a kérdéssel ellátott képek véleményünk szerint inkább minilexikonként müködnek, nem forrásként, hiszen ezek a képek pusztán a tankönyvi leíró szöveg kiegészítői.

A sok negatívum után néhány pozitívumot is ki lehet emelni a megvizsgált tankönyvekböl. Az ötödikes tankönyv a többihez képest több forrásként használható képet tartalmaz. Több kép esetében a kérdések már konkrétan a képekre irányulnak, és nem az előzetes tudást kívánják feltérképezni, hanem maguk a képek az elemzés tárgyai. Például az ötödikes tankönyvben a képi emlékekkel foglalkozó fejezetben látható két fénykép. (7. ábra) Mindkét kép egy sífelvonót ábrázol, miközben az egyik sokkal régebben készült. A képekhez két kérdés társul: Melyik felvétel a régebbi? és Hogyan jöttetek rá, hogy melyik az? Ezeknek a kérdéseknek a megválaszolásához a képeket meg kell vizsgálni. Taxonómiai szempontból az első kérdés egy elemzés, tehát a Bloomi taxonómia negyedik szintje, és a Hogyan jöttél rá...? kérdés is a taxonómia magasabb szintjéhez ér fel. Bár az alacsonyabb szintü taxonómiai lépések hiányoznak, mégis valamenynyire pozitívabb ez a fajta kérdésfeltevés, mint ha nem társulna egyáltalán kérdés a képekhez és ráadásul a kérdések ezekre a konkrét képekre irányulnak, ami szintén pozitívabb.

\section{7. ábra: Sífelvonók összehasonlítása}

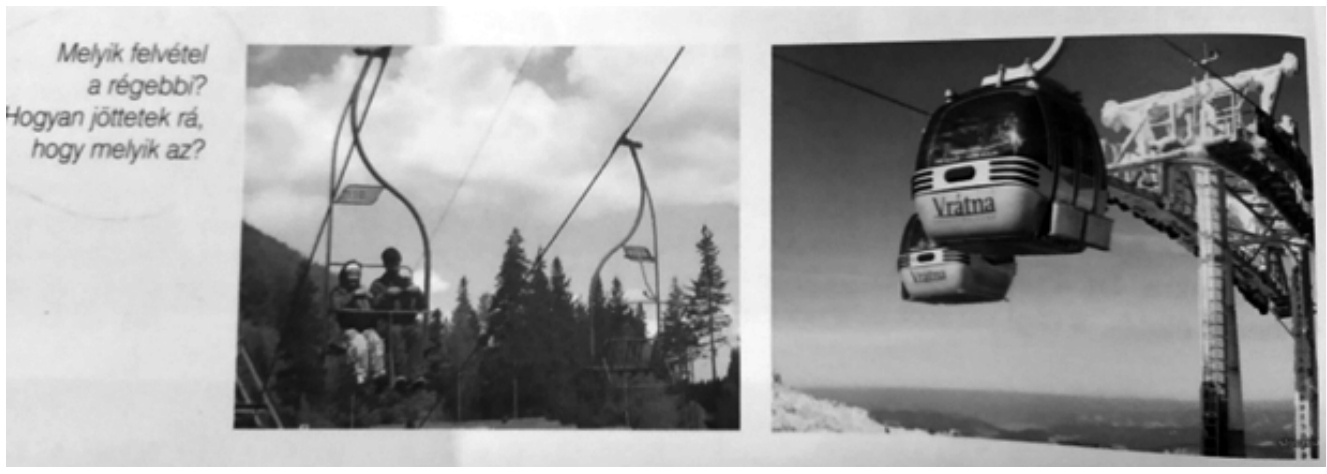

Forrás: Miháliková, Margita - Tonková, MÁRIA (2012): Történelem az alapiskola 5. osztálya számára. Prešov, Slovenské pedagogické nakladatel'stvo. 24. 


\section{Az ELŐSZÓ ÉS A KÉPEK VISZONYA}

Érdekelt bennünket, hogy a tankönyvszerzők milyen célokat fogalmaztak meg az általuk írt vagy szerkesztett tankönyvek képi elemei szempontjából. A három általunk vizsgált tankönyv közül az ötödikes és a hetedikes rendelkezik előszóval, és mindkettő kitér a tankönyvi képek szerepére.

Az ötödikes tankönyv diákoknak szánt előszavában azt olvashatjuk, hogy a képek szerepe a kiemelés és az összegzés, vagyis a szerzők szándéka szerint a képek arra szolgálnak, hogy a leíró szövegben található megtanulnivalóra ráerösítsenek. Vizsgálatunk alapján azt állítjuk, hogy az ötödikes tankönyv esetében a kitüzött cél nagyjából megvalósul, hiszen találtunk olyan képeket és hozzájuk tartozó kérdéseket, amelyek arra szolgálnak, hogy a leíró szövegben tanultakat megerösítsék, kiemeljék. Például a tankönyv 34. oldalán, a fejezet végén, számos kép van felsorakoztatva, és ez a kérdés kapcsolódik hozzájuk: Milyen intézményekben őrzik ezeket a tárgyakat? (8. ábra) A leíró szövegben a képeket megelőző néhány oldalon minden választ megtalálunk a kérdésre, tehát itt ezek a képek egyfajta ismétlő, megerősítő, kiemelő funkciót látnak el.

\section{8. ábra: Milyen intézményekben őrzik ezeket a tárgyakat?}

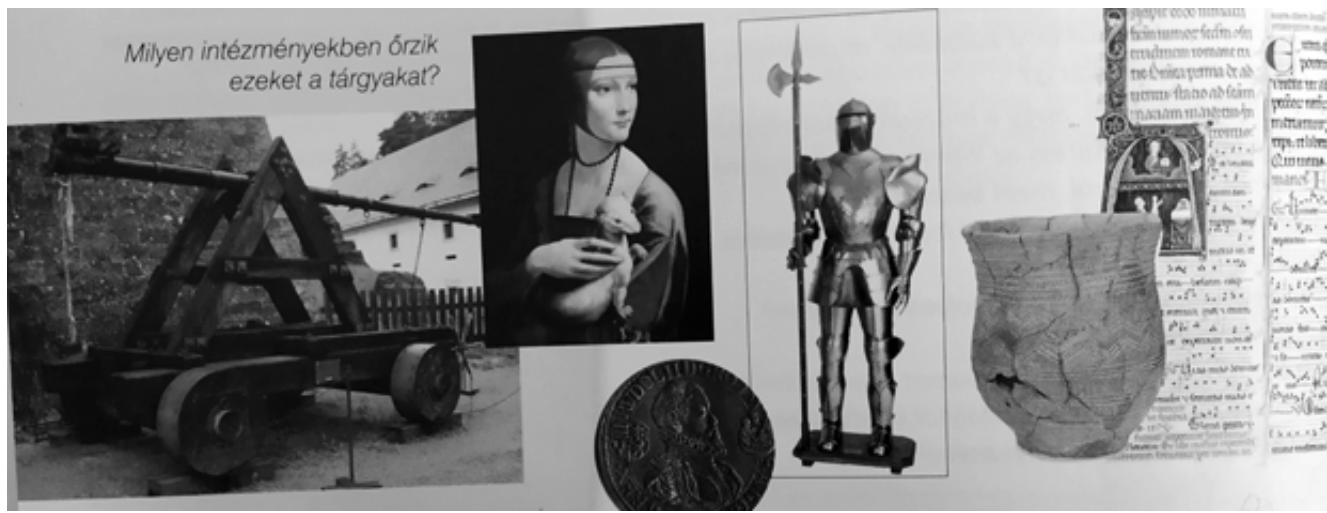

Forrás: MiháLiKová, MARgita - TonKová, MÁRIA (2012): Történelem az alapiskola 5. osztálya számára. Prešov, Slovenské pedagogické nakladatel'stvo. 34.

Érdekesnek találjuk, hogy miközben a képek forrásként való használatának lehetősége a tanulóknak szánt elöszóban fel sem merül, addig a pedagógusoknak szánt elöszóban (nekik van egy külön előszó a könyvben) kiemelik a képeknek azt a szerepét, hogy ,a tankönyvi illusztrációkat használva aktívan sajátítsák el a diákok a történelmi tudást”, tehát a tankönyv illusztrációinak itt a szerzők forrásszerepet szánnak. Erre azonban alig találunk példát. Ugyanezt tapasztaljuk a hetedikes tankönyv előszavában is, amely szerint a képek és a különböző források szerepe az, hogy ,az önálló elsajátítást” segítsék. Azonban megvizsgálva a tankönyv képi elemeit, szinte alig találunk forrásnak tekinthető képeket. A hetedikes tankönyvben a képek 14\%-hoz kapcsolódik kérdés, de a kérdések nagy része nem a képekre irányul, hanem vagy az előzetes tudásra, vagy a tankönyvi leíró szövegre. 
Összességében megállapítható, hogy ahhoz képest, hogy a tankönyv szerzői az előszóban kiemelt szerepet szánnak annak, hogy ,,a tanulók önállóan sajátítsanak el” valamilyen tudást, a képek esetében egyszerüen nem teremtődnek meg ennek feltételei. Azaz a vizsgált tankönyvek képei sokkal inkább illusztrációk, mint források.

\section{A TÉRKÉPEK}

Felfogásunkban a térképek is képek - a bennük rejlő „látható tudás” ennél képibb már nem is lehetne. A térképek tehát olyan képek, amelyek kifejezetten alkalmasak volnának a belölük származó információk gyüjtésére, elemzésére, értelmezésére stb. Ebből kiindulva tartottuk érdemesnek megvizsgálni a térképeket a három szlovákiai tankönyvben, miközben azt feltételeztük, hogy a térképek nagyobb arányban vannak ellátva kérdéssel és feladatokkal, mint a nem térképjellegü képek, ábrák stb.

2.diagram: A térképek aránya

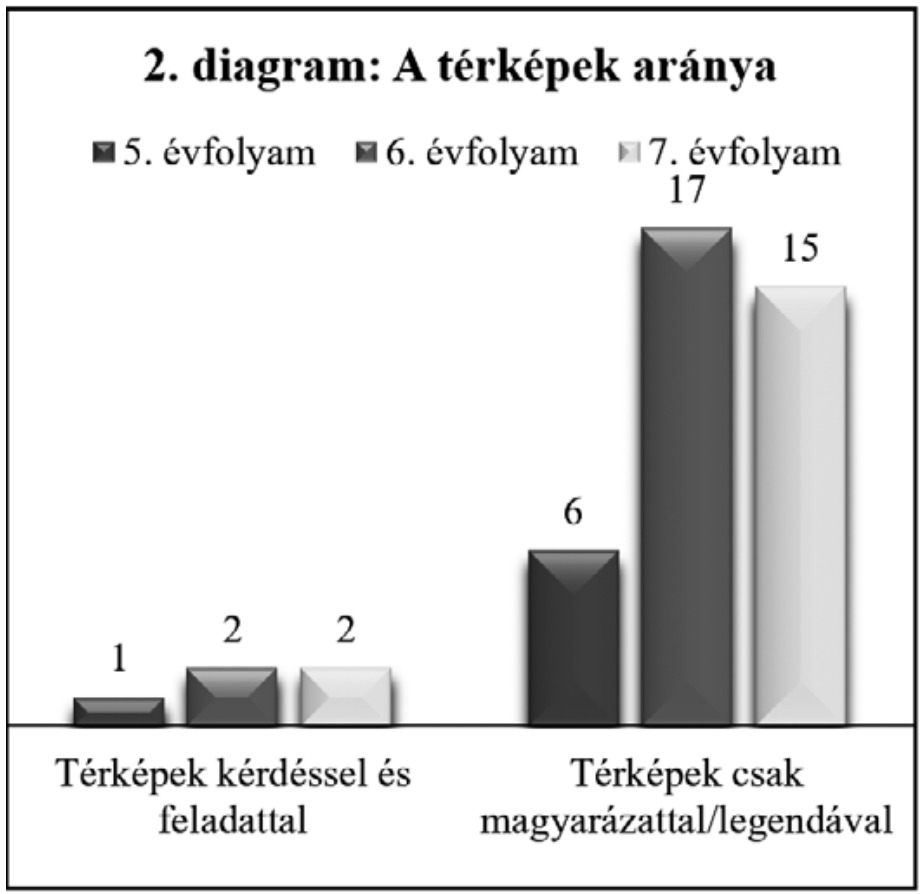

Az 5., 6. és 7. évfolyamos tankönyvekben talált térképek mennyiségét és arányait a 2. számú diagram szemlélteti. Amint láthatjuk, arányaikat tekintve nem nagyban térnek el a térképek a többi típusú képtől a didaktikai kidolgozottság tekintetében. Érthetetlen módon a szöveges magyarázattal és jelmagyarázattal (legendával) ellátott térképek aránya sokkal nagyobb, mint a kérdéssel és feladattal ellátott térképeké. Ez azért furcsa, mert meg vagyunk győződve, hogy az 
iskolai történelmi térképek gyakorlati felhasználhatóságának szinte nincsenek határai - ehhez azonban „,meg kell szólítani” a térképeket, azaz kérdéseket, feladatokat és gyakorlatokat kellene csatolni hozzájuk.

Nem lehet elmenni amellett sem, hogy a 7. évfolyamban a térképek szinte állandóan a változó tér problémájába ütköznek. A mai Szlovák Köztársaság körvonala szinte minden térképen fel van tüntetve, kezdve a Nagy-Morávia kialakulása címü térképpel a 13. oldalon. A mai Szlovák Köztársaság körvonalai felbukkannak még:

- a 23. oldalon a Vármegyék a nyitrai fejedelemség területe címü térképen,

- a 26. oldalon a Nyitrai részfejedelemség $k b$. 1029-ig címü térképen,

- a 31. oldalon a Tatárjárás Magyarországon és a tatárok elvonulása térképén,

- valamint a 35., 36. és 40. oldalon lévő térképeken is.

Tehát a könyvben megjelenített térképeknek majdnem a fele a Szlovák Köztársaság mai területi meghatározását vetíti rá a kb. 1000 és 1400 körüli esztendőket ábrázoló térképekre.

\section{9. ábra: Nagy-Morávia térképe}

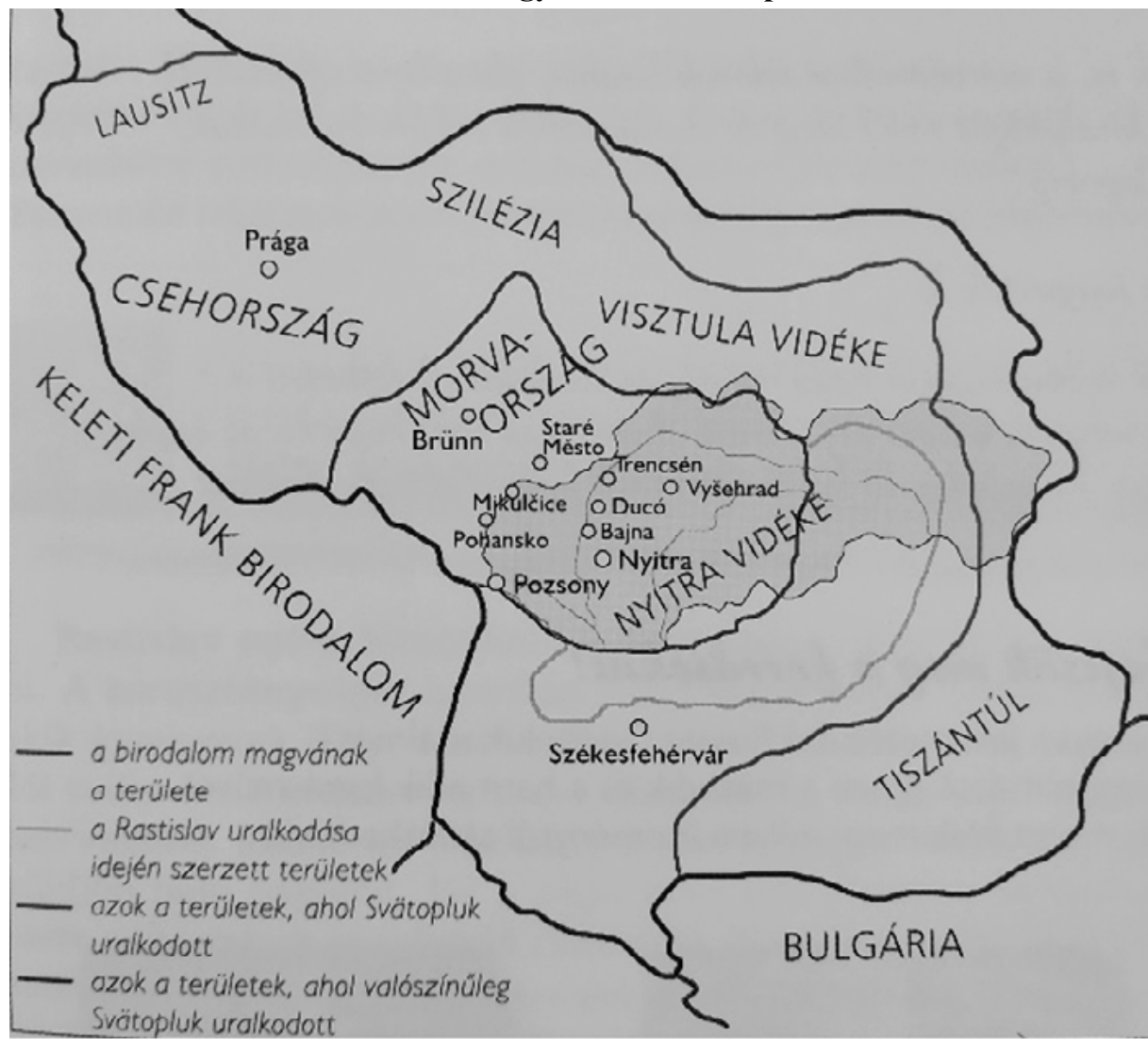

Forrás: LuKAČKA, JÁN - TONKOvÁ, MÁRIA- KAČÍREK ĹuBOŠ- SoŇA HANOvÁ (2012): Történelem az alapiskola 7. osztálya számára és a nyolcosztályos gimnázium 2. osztálya számára. Prešov, Slovenské pedagogické nakladatel'stvo. 13. 
10. ábra: Magyarország területének a felosztása a király és a fóurak között a 14. század első két évtizedében
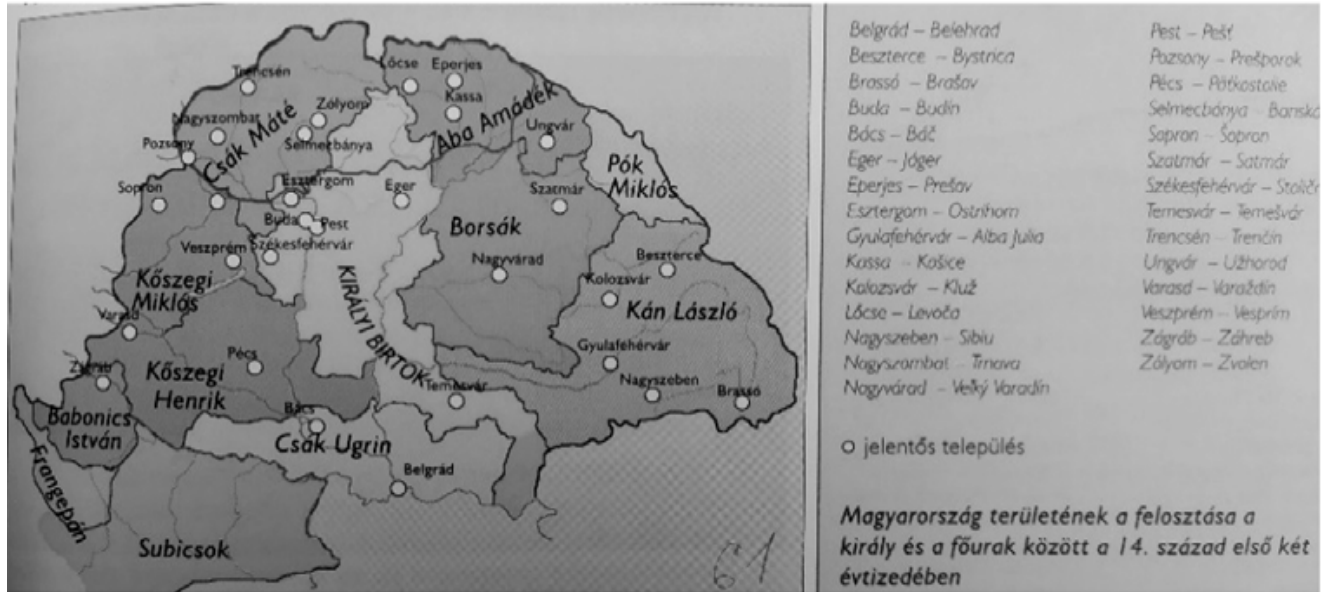

Forrás: LuKAČKA, JÁN - TONKOVÁ, MÁRIA- KAČÍREK ĹUBoš- SoŇA HANOvá (2012): Történelem az alapiskola 7. osztálya számára és a nyolcosztályos gimnázium 2. osztálya számára. Prešov, Slovenské pedagogické nakladatel'stvo. 35

\section{A KÉRDÉSEKKEL ELLÁTOTT TÉRKÉPEK}

A térképek használata gyakorlást igényel. A térképeket használva megállapíthatjuk, hogy mikor kik vettek részt például egy hadjáratban, mi lett annak végkimenetele és felfedezhetünk különböző összefüggéseket. (SzÁRAY 2020) Példaként, ha a vizsgált könyvsorozatunk 7. évfolyamának szánt tankönyvében a 31. oldalon a Tatárjárás Magyarországon és a tatárok elvonulása térkép helyett egy nagyobb, részletesebb tatárjárást bemutató térkép lenne elhelyezve, a hozzácsatolt megfelelö kérdésekkel, akkor a felette található szöveg a Muhi csatáról és IV. Béla meneküléséröl szinte feleslegessé válna.

\section{1. ábra: A tatárjárás Magyarországon és a tatárok elvonulása}
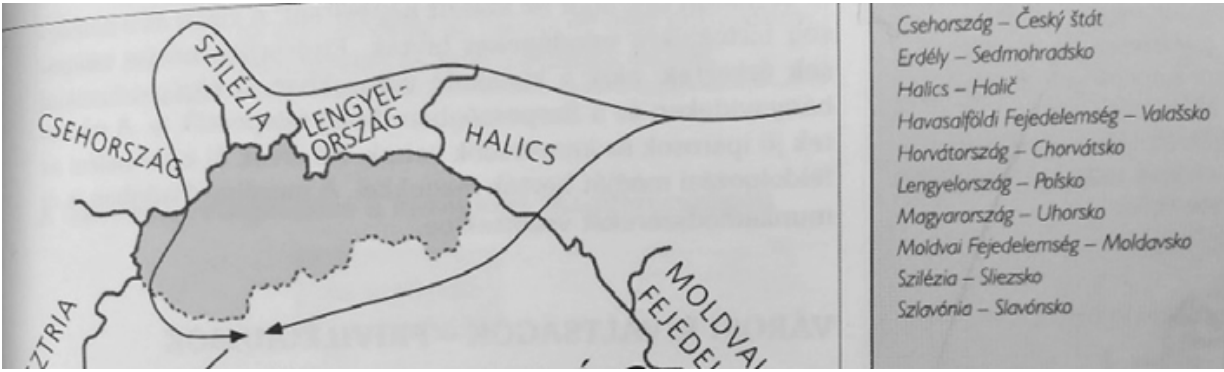

Forrás: LukačKa, JÁN - Tonková, MÁRIA- KaČíReK Ĺuboš- SoŇA HanovÁ (2012): Történelem az alapiskola 7. osztálya számára és a nyolcosztályos gimnázium 2. osztálya számára. Prešov, Slovenské pedagogické nakladatel'stvo. 31 


\section{2. ábra: Tatárjárás Magyarország (példa egy részletesebb térképre)}

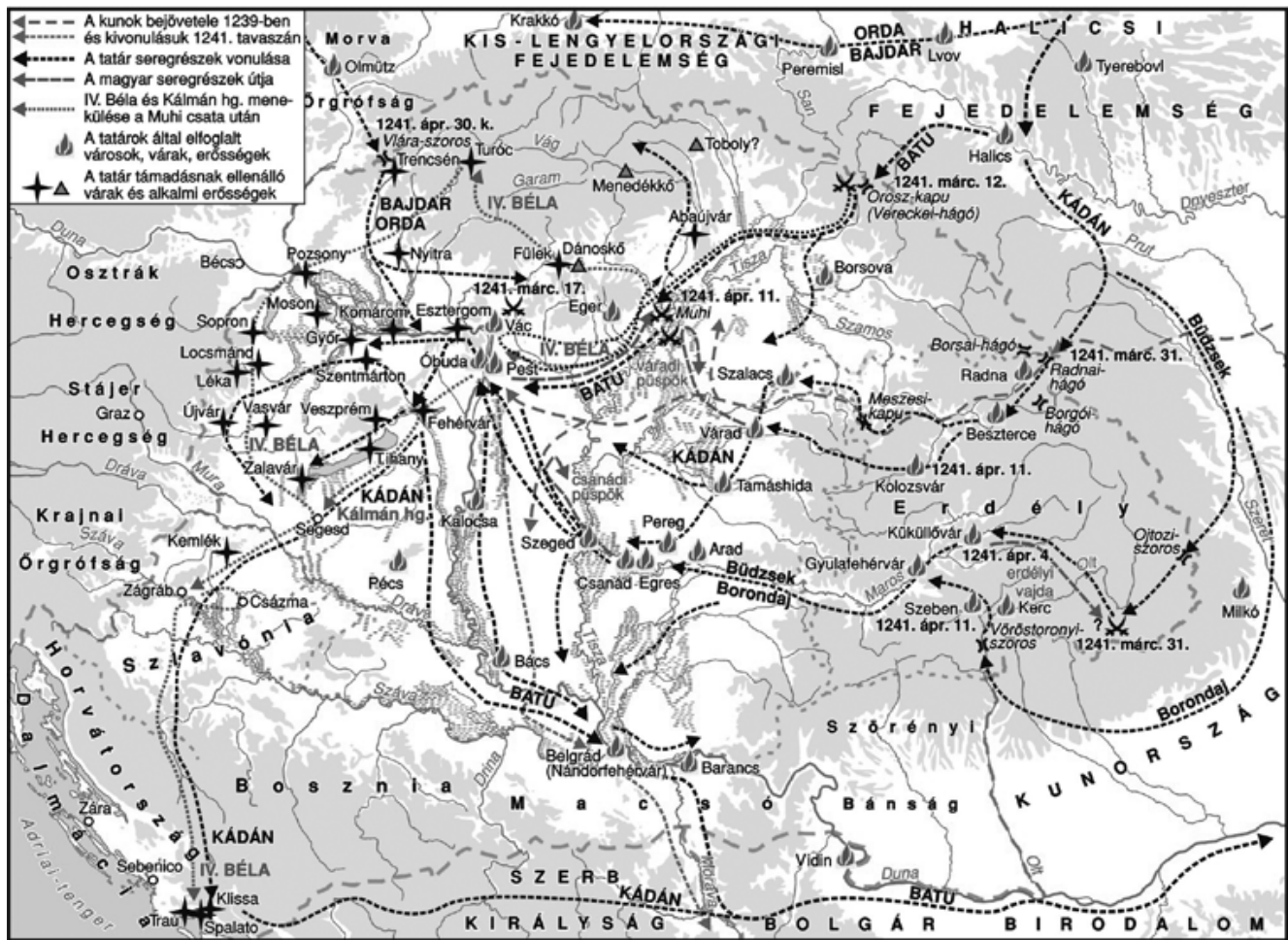

\section{TATÁRJÁRÁS MAGYARORSZÁGON (1241--1242)}

Forrás: E-kompetencia http://www.e-kompetencia.si/egradiva/mad_zgo/04/a_tatrjrs_folyamata.html

Javaslatként az alábbi kérdéseket lehetne egy részletesebb tatárjárással kapcsolatos térképhez kapcsolni:

Nézd meg a térképet! Határozd meg a térkép feliratainak segitségével, hogy melyik országot és melyik időszakot ábrázolja a térkép!

Keresd meg, azonositsd a legfontosabb csaták helyszinét a térképen!

Keress és nevezz meg négy várat, amelyek nem tudtak ellenállni a tatároknak, és négy másikat, amelyek ellen tudtak állni. Vesd össze a várak földrajzi elhelyezkedését, és vonj le ebböl következtetéseket.

Kövesd a térképen Batu kán útvonalát, közben meséld el, merre haladt és mi történt az útja közben! 
Állapitsd meg a térképen, hol tünt el IV. Béla a Muhi csata után! Vonj le következtetéseket ebböl a harcok kimenetelével kapcsolatban.

Ítéld meg a tatárjárás sikerességét a tatárok szempontjából, valamint értékeld a magyar várak ellenállóképességét a magyarok szempontjából!

A térképek egyik jó tulajdonsága a tömörítés, amit ha a tankönyvszerzők kihasználnának, akár a leíró szöveget is sikeresen ki tudnák váltani nem egy esetben. Amint a fenti kérdésekből és feladatokból is látható, a forrásként alkalmazott térképhez csatolt kérdések lefedik az általános iskolások tudnivalójának jelentős részét a témáról, ráadásul a térkép elemzése által több képességük is fejlődik.

\section{ÖsszEGzÉS}

F. Dárdai Ágnes a megfelelő képretorikával kapcsolatosan megállapítot kritériumait alapul véve (F. DÁRDAI 2008. 109.) megállapíthatjuk, hogy a vizsgált három szlovákiai alapiskolás történelemtankönyvben a változatos, különböző műfaji kategóriákat felsorakoztató képanyag próbál igazodni a tanulók megváltozott vizuális kultúrájához, azonban egyértelmüen nem vagy alig haladják meg a puszta dekoratív, illusztratív funkciót, vagyis nem töltik be a tőlük elvárható didaktikai funkciókat, szerepeket, lehetöségeket.

A tankönyvi ábrák mérete miatt, valamint a hozzájuk kapcsolt kérdések, feladatok és gyakorlatok elhanyagolható mennyisége és alacsony didaktikai előkészítettsége miatt a vizsgált képek puszta dekoratív szerepet látnak el, így forrásnak nem, csupán illusztrációknak tekinthetők. Sajnos nem túlzó az a megállapítás, hogy a kérdéseknek és a feladatoknak a vizsgált tankönyvek szerzői, szerkesztői nem sok pedagógiai funkciót szántak. A térképek is hasonló problémákkal küszködnek, mint a tankönyvek egyéb képei. Kevés a hozzájuk csatolt kérdés és feladat, túlságosan le vannak egyszerüsítve és még a változó tér problémája is nagyon sok esetben felmerül. Mindeközben úgy véljük, hogy a térképekben is sokkal több potenciál rejlik. A használatukkal fejleszthető volna a tanulók földrajzi lokalizációs képessége, megtanulhatnának információkat leolvasni egy bonyolult vagy egyszerüsített térképről, és gyakorolhatnák a verbalizációt is.

Meglátásunk szerint a vizsgált tankönyvek nagyszerü képeket tartalmaznak, amelyek, ha nagyobb méretűek lennének, továbbá, ha el lennének látva megfelelő, azaz didaktikailag átgondolt (taxonomizált) kérdésekkel, feladatokkal és gyakorlatokkal, akkor nagyon könnyen válhatnának a tudás forrásaivá. Sajnos Szlovákiában keserü tapasztalat, hogy a tankönyvekből hiányzó taxonomizált feladatok elkészítése a tanárokra marad - és ők, valljuk meg, nem mindig tudják vagy akarják felvállalni ezt a pluszfeladatot. A tankönyvi képek tekintetében az itt vizsgált tankönyvsorozat készítői nem törekedtek arra, hogy a leíró szövegben közölt ismeretek mellett, ezekkel párhuzamosan a tanulók ismeretei a képek önálló értelmezéseiből származzanak. 


\section{FeLHASZNÁLT IRODALOM}

FisCHERnÉ DÁRDAI ÁGNES (2008): Szempontok a tankönyvi képek ikonológiai és ikonográfiai értelmezéséhez. In Bábosik István (szerk.): Az iskola korszerü funkciói. Budapest, Okker Kft.

Fischerné DÁRDAi ÁGNES - KoJAnitz LÁszló (2007): A tankönyvek változásai az 1970-es évektől napjainkig. Új Pedagógiai Szemle 57. évf. 1. sz. 56-69.

GÉCZI JÁNOS (2008): Ikonológia-ikonográfia mint a történeti pedagógia segédtudománya. Iskolakultúra 18. évf. 1. sz. 108-119. https://ojs.bibl.u-szeged.hu/index.php/iskolakultura/ article/view/20718/20508

KAPOSI JÓzSEF (2020): Közelítések a történelemtanítás elméletéhez és gyakorlatához. Budapest, Pázmány Péter Katolikus Egyetem. http://kaposijozsef.hu/wp-content/uploads/2020/07/ Kozelitesek_kotet_nyomdai_javitott.pdf

KoJANitz LÁszló (2004): A tankönyvek használhatóságát meghatározó minőségi összetevők elemzése és összehasonlitása. Nemzeti Erőforrás Minisztérium.

http://www.nefmi.gov.hu/letolt/kozokt/tankonyvkutatasok/cd1_kojanitz/vizsgalat_ eredmenyeinek_bemutatasa.pdf. Letöltés dátuma: 2021.05.10.

Krasnovský, BranislaV - Miháliková, Margita - Tonková, Mária (2016): Történelem az alapiskola 6. osztálya számára és a nyolcosztályos gimnázium 1. osztálya számára. Bratislava, Slovenské pedagogické nakladatel'stvo.

LuKaČKA, JÁN - TONKOVÁ, MÁRIA- KAČÍreK Ĺuboš - SoŇA HANOvá (2012): Történelem az alapiskola 7. osztálya számára és a nyolcosztályos gimnázium 2. osztálya számára. Prešov, Slovenské pedagogické nakladatel'stvo.

MARóDI ÁGNES (2013): A tankönyvi képek és illusztrációk szerepe az oktatásban. (The educational role of coursebook illustrations) Belvedere Meridionale. XXV. évf. 4. sz. 101-107. http://publicatio.bibl.u-szeged.hu/15858/1/belvedere_2013_004_101-107_ Atankonyviillusztraciokeskepekszerepeazoktatasban.pdf

SzÁRAY MikLós (2020): A térkép szerepe és elemzése a történelemórán. Történelemtanitás. (XLV.) Új folyam I. -2. szám

http://www.folyoirat.tortenelemtanitas.hu/2010/05/szaray-miklos-a-terkep-szerepe-es elemzese-a-tortenelemoran/ letöltve: 2021.05.20.

Miháliková, Margita - Tonková, MáRIA (2012): Történelem az alapiskola 5. osztálya számára. Prešov, Slovenské pedagogické nakladatel'stvo.

VAJDA BARnABÁS (2018): Bevezetés a történelemdidaktikába és történelemmetodikába. Komárom, Selye János Egyetem. 115.

VAJDA BARNABÁs (2020): Történelemdidaktika és történelemtankönyv-kutatás. Komárom, Selye János Egyetem.

VAJDA BARNABÁs - BÉNYI KlaUdia (2011): A képekröl mint tankönyves történelmi forrásokról - egy tudományos diákköri munka kapcsán. Eruditio - Educatio 6. évf. 4. sz. 111-118. 
ZÁvoDSZKY GÉZA (1986): Néhány szempont a tankönyvi kép ervezéséhez és kritikájához. In Karlovitz, János (szerk.): Tankönyvelméleti tanulmányok. Budapest, Tankönyvkiadó.

V. MolnÁr LÁszló (2001): A tankönyvi illusztráció, mint megismerési bázis. In Szabolcs Ottó (szerk.): Történelempedagógiai füzetek 8. Budapest, Tóthfalusi Tannyomda. 